\title{
Den populære krig?
}

Upopulære krige er svære at vinde. Populære krige er svære at tabe.

I Irak har de danske soldater lidt under en heftig indenrigspolitisk strid på hjemmefronten. I Afghanistan-krigen er det nu oppositionslederen, Helle Thorning, der udbassunerer, at vi bliver i landet, til krigen er vundet. Og bortset fra det yderste venstre er der enighed om, at denne krig er en lakmusprøve på NATOs fremtid.

Med advarselslamperne blinker, og derfor sætter dette nummer af Udenrigs fokus på Afghanistan.

Taleban-bevægelsen er på vej frem snarere end tilbage. Samtidig begår NATO-styrker uundgåelige fejltagelser, som nødvendigvis må tære på civilbefolkningens tålmodighed.

$\mathrm{Nu}$ gælder det om at vinde hearts and minds. Det gælder om at uddanne lokale politi- og sikkerhedsstyrker. Det gælder om at sikre en balance mellem civile og militære indsatsområder. Det gælder om at sikre lov og ret, om at få landet til at hænge sammen.

Ret beset kan den regionale sikkerhedssituation i Central- og Sydasien ligeså lidt tåle et nederlag som krigen i Irak. Begge steder bidrager naboer til truslen om opløsning. I Afghanistan spiller én af vore officielle 'allierede' i krigen mod terror Pakistan - en tvivlsom dobbeltrolle.
Reelt tjener de pakistanske grænseprovinser som bagland for Talebanbevægelsens krigsførelse i Afghanistan. Og det er USA's formodning, at al-Qaeda-terrornetværkets efterlyste Godfather, Osama bin-Laden, skjuler sig i disse uvejsomme områder.

Selv hvis NATO fæstede lid til det pakistanske diktatur, ville det være foruroligende, at det pakistanske regime ikke er i stand til at kontrollere sit eget territorium. Og selv om Pakistan hævder at deltage i jagten på Osama bin-Laden, er det dybt foruroligende, at en dusør svarende til halvanden hundrede millioner kroner ikke får en eneste fugl til at synge i nogle af verdens fattigste områder.

På denne baggrund skal krigen i Afghanistan udkæmpes, og uanset store ord om den civile indsats, er den militære kamp allerede ved at få overbalance i forhold til den civile.

Dilemmaet er, at NATO, regeringen og oppositionen ikke har råd til at tabe; men at det kan blive dyrt at føre krigen til sejr.

\section{Redaktionen}

Torben Krogh, mangeårig redaktør af 'Udenrigs', skriver om det danske Afghanistan-bidrag. Det skulle blive hans sidste artikel, før han afgik ved døden den 26. juni. Nekrolog naste opslag. 